\title{
Konstruksi Makna Pesan Dakwah pada Program Pendidikan dan Pelatihan Virtual Santri Siap Guna (SSG) Angkatan 40 Pondok Pesantren X Bandung di Masa Pandemi Covid-19
}

\author{
Dhovi Rizal Fachrudin* \\ Prodi Komunikasi Penyiaran Islam, Fakultas Dakwah, Universitas Islam \\ Bandung, Indonesia. \\ *dhovi.fachrudin21@gmail.com
}

\begin{abstract}
Delivery, one can take advantage of various kinds of media, including non-formal media. At the beginning of 2020 the world experienced a pandemic that had a major impact on various sectors, one of which was affected by the pandemic was the non-formal education program held by Pondok Pesantren X Bandung, namely, the education and training program for students who were ready to use Daruut Tauhiid Bandung. The implementation of this program puts forward the character of BAKU (Good and Strong) where in its activities it uses a semi-military system that requires faceto-face contact. Based on this phenomenon, the researcher conducted a study with the title Construction Phenomenology Study Of The Meaning Of Dakwah Messages In The Covid-19 Pandemic (Case Study In Virtual SSG Education And Training Program For The 40 Pondok Pesantren X Bandung). This study aims to examine how the meaning of da'wah messages through the SSG education and training program is virtually for batch 40 participants and to find out how to construct the meaning of da'wah messages in the program by studying the values of da'wah, motives and experiences understood by the participants. This study uses qualitative methods and a phenomenological approach with 10 informants. Data were obtained through in-depth interviews, observation, literature study and documentation. The results obtained from this study are (1). The values contained in the message of the program's da'wah are categorized into three, namely, Aqidah, Akhlak and Sharia. (2) the motive of the reader is divided into two, namely the motive of encouragement and the motive of hope. (3) the reader's experience is divided into two, namely, positive experiences and negative experiences. Overall, the message of the program's da'wah has a meaning.
\end{abstract}

Keywords: Dakwah, Phenomenology, Meaning Constituency.

\begin{abstract}
Abstrak. Dalam kegiatan dakwah, pesan merupakan inti utama dari komunikasi yang sifatnya abstrak. Dalam penyampaiannya, seorang dapat memanfaatkan berbagai macam media termasuk media non formal. Di awal tahun 2020 dunia mengalami pandemi yang berdampak besar terhadap berbagai sektor salah satu yang terkena dampak pandemi adalah program pendidikan non formal yang di adakan oleh Pondok Pesantren X Bandung yaitu, program pendidikkan dan pelatihan santri siap guna Daruut Tauhiid Bandung. Pelaksanaan program ini mengedepankan karakter BAKU (BAik dan KUat) dimana dalam aktivitasnya menggunakan sistem semi militer yang mengharuskan selalu bertatap muka. Berdasarkan fenomena tersebut, peneliti melakukan penelitian dengan judul Studi Fenomenologi Konstruksi Makna Pesan Dakwah Di Masa Pandemi Covid-19 (Studi Kasus Pada Program Pendidikkan dan Pelatihan Virtual SSG Angkatan 40 Pondok Pesantren X Bandung). Penelitian ini bertujuan untuk mengkaji bagaimana pemaknaan pesan dakwah melalui Program Pendidikkan dan pelatihan SSG secara virtual pada peserta angkatan 40 serta mengetahui bagaimana konstruksi makna pesan dakwah dalam Program tersebut dengan mengakaji nilai dakwah, motif dan pengalaman yang dipahami para peserta. Penelitian ini menggunakan metode kualitatif dan pendekatan fenomenologi dengan informan yang berjumlah 10 orang. Data diperoleh melalui wawancara mendalam, observasi, studi pustaka dan dokumentasi. Hasil yang didapatkan dari penelitian ini adalah (1). Nilai yang terkandung dalam pesan dakwah program tersebut dikategorikan menjadi tiga yaitu, Aqidah, Akhlak dan Syariah. (2) motif pembaca terbagi menjadi dua yaitu motif pendorong dan motif harapan. (3) pengalaman pembaca terbagi menjadi dua yaitu, pengalaman positif dan pengalaman negatif. Secara keseluruhan, pesan dakwah Program tersebut memiliki makna sebagai bentuk ikhtiar para peserta dalam meningkatkan kualitas diri.
\end{abstract}

Kata Kunci: Dakwah, Fenomenologi, Konstruksi makna.. 


\section{A. Pendahuluan}

Karena Islam adalah agama dakwah maka umat Islam berkewajiban melaksanakan ajaran Islam dalam keseharian hidupnya dan harus menyampaikan atau mendakwahkan kebenaran ajaran Islam terhadap orang lain. Mengajak kebaikan dan mencegah kemungkaran. Penyampaian pesan dakwah juga tidak harus menunggu kesempatan-kesempatan formal seperti majelis taklim, pengajian maupun kesempatan sejenis. Melainkan masih banyak media dan ruang secara non formal juga yang dapat dilaksanakan seperti mengikuti pelatihan pelatihan yang berhubungan dengan nilai nilai keIslaman.

Di awal tahun 2020, dunia dihebohkan dengan merebaknya virus Corona (Covid-19) yang kemudian menginfeksi hampir seluruh negara di dunia. Covid-19 pertama kali muncul di Wuhan, Provinsi Hubei pada 31 Desember 2019. Wabah virus ini bukan pertama kali dialami negara-negara di dunia. Dampak pandemi Covid-19 ini mempengaruhi terhadap perekonomian, sosial, keamanan, serta politik serta kondisi psikologis dan perubahan perilaku yang sifatnya lebih luas dalam jangka waktu yang lebih panjang. Perubahan perilaku tersebut mencakup perilaku hidup sehat, perilaku menggunakan teknologi, perilaku dalam pendidikan, perilaku menggunakan media sosial, perilaku konsumtif, perilaku kerja, dan perilaku sosial keagamaan.

Penggunaan teknologi yang tadinya sebagai pendukung kerja sekunder atau malah rekreasi, berubah menjadi fasilitas kerja utama. Hal ini juga berdampak pada negara Indonesia salah satunya pada sistem pendidikan, baik itu pendidikan secara formal maupun nonformal. Pendidikan di Indonesia mengalami perubahan sistem karena pemerintah membuat keputusan untuk mengubah proses pembelajaran dan aktifitas pendidikkan yang tadinya dilakukan secara tatap muka secara langsung menjadi di rumah. Peralihan pembelajaran ini mamaksa berbagai pihak untuk mengikuti alur yang sekiranya bisa ditempuh agar pembelajaran dapat berlangsung dengan cara memanfaatkan teknologi sebagai media pembelajaran daring.

Hal tersebut di alami oleh salah satu Pendidikan Non formal di Indonesia yaitu Program Pendidikan dan Pelatihan Santri Siap Guna Pondok Pesantren X Bandung yang menekankan pada pembentukan karakter generasi muda. Pendidikkan dan pelatihan Santri Siap Guna Pondok Pesantren X Bandung, hadir pertama kali pada 25 April 1999, berawal dari perenungan pimpinan Pondok Pesantren X Bandung, K.H. Abdullah Gymnastiar, yang biasa di sapa dengan Aa Gym. Beragam permasalahan di negeri yang mayoritas Islam ini pangkal nya adalah masalah akhlaq. Aa Gym bertekad untuk mencoba mencari solusi dengan merancang dan menyelenggarakan Pendidikan dan pelatihan untuk membina akhlaq pada generasi muda agar memiliki akhlaqul karimah. Pada perkembangan berikutnya Aa Gym mendefinisikan konsepsi pendidikkan dan pelatihan karakter santri siap guna dengan konsepsi pendidikkan dan pelatihan karakter BAKU singkatan dari Baik dan Kuat. Karakter Baik yaitu Ikhlas, Jujur, Tawadhu. sedangkan Karakter Kuat terdiri atas Disiplin, Berani, Tangguh dengan pendekatan visi sebagai pelayanan masyarakat baik dibidang dakwah, ekonomi maupun sosial kemasyarakatan.

Peneliti mengambil subjek program pendidikkan dan pelatihan virtual santri siap guna angkatan 40 karena berdasarkan observasi tersebut bahwa banyak tanggapan positif dari para peserta Angkatan sebelumnya yang dilaksanakan secara offline. Akan tetapi, seiring adanya wabah covid-19 pada program pendidikkan dan pelatihan santri siap guna angkatan 40 maka dilaksanakannya secara online dengan mengoptimalkan berbagai Flatform seperti Zoom, Google Classroom, Instagram, Whatsapp dan Google Meet. Kegiatan ini dilaksanakan setiap hari minggu selama 12 pekan pertemuan dengan peserta 134 orang. Hal tersebut menarik peneliti untuk lebih jauh mengetahui makna pesan dakwah, pada program pendidikkan dan pelatihan santri siap guna angkatan 40 .

Pemaknaan pesan dakwah yang dilakukan oleh peserta program pendidikkan dan pelatihan santri siap guna angkatan 40 tidak terlepas dari pengalaman selama mengikuti pendidikkan dan pelatihan virtual santri siap guna angkatan 40 tersebut. Ketika mengikuti pendidikkan dan pelatihan program santri siap guna 40 pesan dakwah apa saja yang peserta dapatkan, ia bukan hanya menginterpretasikan pengalaman pribadi, tetapi ia juga menginterpretasikan pengalaman orang lain yang ia ikuti pada program pendidikkan dan pelatihan santri siap guna 40 . 
Proses interaksi yang dilakukan oleh peserta program pendidikkan dan pelatihan virtual santri siap guna angkatan 40 dalam konsepsi fenomenologi akan melahirkan motif-motif tertentu yang dimiliki seseorang. Motif-motif tersebut akan berbeda dalam membangun makna didalam kegiatan sehari-hari peserta program pendidikkan dan pelatihan virtual santri siap guna Angkatan 40. Bedasarkan uraian tersebut peneliti tertarik untuk mengetahui bagaimana konstruksi makna pesan dakwah program pendidikkan dan pelatihan virtual santri siap guna angkatan 40 Pondok Pesantren X Bandung di masa pandemi Covid-19 dengan menggunakan pendekatan fenomenologi.

Selanjutnya, tujuan dalam penelitian ini diuraikan dalam pokok-pokok sbb.

1. Untuk mengetahui dan mengkaji tahapan apa saja terdapat pada program pendidikkan dan pelatihan virtual santri siap guna Angkatan 40 Daruut Tauhiid di masa pandemi covid 19.

2. Untuk mengetahui dan mengkaji pesan dakwah yang terdapat pada Pendidikan dan Pelatihan virtual Santri Siap Guna Angkatan 40 Pondok Pesantren X di masa pandemi covid 19.

3. Untuk mengetahui dan mengkaji fenomenologi konstruksi makna pesan dakwah pada peserta Pendidikan dan Pelatihan virtual Santri Siap Guna Angkatan 40 Pondok Pesantren X di masa pandemi covid 19.

\section{B. Metodologi Penelitian}

Penelitian ini menggunakan metode kualitatif dan pendekatan fenomenologi dengan informan yang berjumlah 10 orang. Informan dipilih acak dari peserta program Pendidikan dan Pelatihan Santri Siap Guna Pondok Pesantren X Bandung Angkatan 40. Data diperoleh melalui wawancara mendalam, observasi, studi pustaka dan dokumentasi. Adapun teknis analisis data yang digunakan adalah Teknik triangulagi data dan reduksi data.

\section{Hasil Penelitian dan Pembahasan}

Pesan komunikasi dalam kegiatan dakwah disebut dengan materi dakwah baik berupa akidah, ibadah, muamalah dan akhlak yang diajarkan Allah SWT dalam Al-Qur'an. Sementara hadits Rasulullah SAW merupakan hikmah petunjuk kebenaran. Oleh karena itu, pesan dakwah tidak terlepas dari kedua sumber tersebut, bahkan jika tidak berpedoman dari keduanya maka aktivitas dakwah dan akan sia-sia. Maddah (materi dakwah) adalah masalah isi pesan atau materi yang disampaikan da'i pada mad'u. Dalam hal ini sudah jelas bahwa yang menjadi maddah dakwah adalah ajaran Islam itu sendiri, sebab semua ajaran Islam yang sangat luas itu bisa dijadikan maddah dakwah Islam. Akan tetapi ajaran Islam yang dijadikan maddah dakwah itu pada garis besarnya terdiri dari Aqidah, syari'ah dan akhlak. Sejalan denga napa yang si sampaikan oleh 10 orang informan.

Bagi Schutz makna dapat diinterpretasikan dari berbagai perspektif manusia sebagai mahluk sosial. Makna dilahirkan berdasarkan pada sebuah pengalaman yang subjektif, yang dikonstruksikan dalam diri manusia sebagai mahluk yang merdeka. Individu yang aktif dalam proses pemberian makna, bahwa setiap manusia memaknai realitas berdasarkan pada apa yang pernah dilihat, didengar, dan dirasakan sebagai pengalaman nyata. Makna hadir dan dihadirkan sebagai konsekuensi atas apa yang dirasakan oleh manusia. Schutz juga menjelaskan, untuk menggambarkan tujuan suatu tindakan sosial seseorang itu cukup kompleks, sebuah makna yang rumit atau makna yang kontekstual. Dalam wawancara yang dilakukan dengan 10 orang informan ditemukan setidaknya 2 motif yaitu because motive dan in order to motive.

Selain itu juga Fenomenologi menjadikan pengalaman yang sebenarnya sebagai data utama dalam memahami realitas, apa yang diketahui seseorang adalah apa yang dialaminya. Jika ingin mengetahui apa itu "cinta", maka anda tidak akan bertanya kepada orang lain, tetapi anda langsung memahami cinta melalui pengalaman langsung diri sendiri. Dengan kata lain, fenomenologi telah mengklaim dirinya sebagai suatu ilmu pengetahuan tentang sifat-sifat alami kesadaran dan pengetahuan orang pertama melalui bentuk-bentuk intuisi. 
Sebuah pengalaman dapat disebut sebagai suatu pengalaman yang positif manakala isi, konteks, dan dampak dari peristiwa yang dialami tersebut dipahami dan dirasakan individu sebagai sesuatu yang bersifat memberdayakan secara langsung. Disisi lain, tidak semua pengalaman bernuansa positif, terdapat beberapa peristiwa yang dapat dikategorikan pengalaman negatif. Pengalaman yang negatif dapat dijelaskan sebagai peristiwa yang telah dialami, manakala isi, konteks, dan dampak yang dirasakan dan dipahami oleh individu sebagai suatu hal yang akan dapat menimbulkan perasaan tidak menyenangkan (malu, sedih, kecewa, kesal). Dalam wawancara mandalam yang dilakukan oleh peneliti kepada 10 orang informan, menghasilka 2 kategori pengalaman yaitu, pengakam positif dan pengalam negative.

\section{Kesimpulan}

Berdasarkan pembahasan dalam penelitian ini, peneliti menyimpulkan beberapa hasil penelitian sebagai berikut:

1. Program yang ada di pendidikkan dan pelatihan santri siap guna yang pertama adalah, Tahap Dobrak Diri secara khusus adalah tahap untuk membangun persepsi, frekuensi yang sama dari semua peserta, menurunkan ego serta mendobrak penghambatpenghambat. Yang kedua Tahap Bangun diri diisi oleh materi-materi atau pembiasanpembiasan, tata nilai budaya khas Pondok Pesantren X dan yang ketiga adalah Tahap Bangun team, Tahap ini merupakan tahapan untuk memperkenalkan, melatih peserta untuk memiliki rasa sepenanggungan, kebersamaan, kepekaan sosial dan kesiapan serta kemauan berkontribusi untuk masyarakat.

2. Ke tiga tahap tersebut lebih menekankan pada penentuan muatan materi sesuai tahapannya, namun pada dasarnya nilai Karakter Baku dapat ditemukan, dipelajari, dilatih dan dibangun disetiap tahap dan saling melengkapi dan menguatkan.

3. Pesan yang dipahami oleh para informan bersumber dari agama Islam. Semua informan menyebutkan lebih dari satu pesan dakwah yang ia tagkap dari Pendidikan dan pelatihan SSG. Hal ini menunjukan keragaman pesan yang terkandung didalamnya. Adapun didalam Pendidikan dan Pelatihan Santri Siap Guna dalam setiap materinya mengandung pesan Aqidah, Akhlak, Syariah. Pesan Aqidah yang terkandung didalamnya merupakan pesan ketauhidan dalam upaya mengesakan Tuhan, didalam penelitian ini, ada 7 orang informan yang menyebutkan bahwa Pendidikan dan Pelatihan SSG megandung Pesan Aqidah. Pesan Akhlak yang disampaikan para informan merupakan pesan yang menunjukan keragaman perilaku, didalam penelitian ini ada 8 orang yang menyebutkan bahwa Pendidikan dan Pelatihan SSG megandung Pesan Akhlak. Adapun Pesan Syariah merupakan pesan dakwah yang membahas pokok-pokok ibadah yang dalam penelitian ini ada 2 orang informan berpendapat bahwa Pendidikan dan Pelatihan SSG megandung Pesan Syariah.

4. Terlihat bahwa pada pendidikkan dan pelatihan virtual santri siap guna Angkatan 40 memiliki semua pilar keIslaman yaitu, aqidah, akhlak, dan syariah akan tetapi ulasan mengenai aqidah dan akhlak mendominasi. karenakan sesuai dengan tujuan daripada pendidikkan dan pelatihan virtual santri siap guna yang berfokus terhadap pembentukan dan pembinaan akhlak.

5. Konstruksi makna pesan dakwah program pendidikkan dan pelatihan virtual santri siap guna Angkatan 40, Dari penuturan pesan dakwah, motif dan pengalaman yang di sampaikan oleh para peserta Pendidikan dan Pelatihan Virtual Santri Siap Guna Angkatan 40, maka konstruksi makna dari pesan dakwah dalam Pendidikan dan pelatihan virtual santri siap guna Angkatan 40 secara umum yaitu merupakan bentuk ikhtiar para peserta dalam meningkatkan kualitas diri dan mendapatkan ridho Allah Swt. Pesan-pesan yang disebutkan para peserta juga sangat bermakna dalam memotivasi dan memberikan hikmah dibalik setiap kegiatan yang diselenggarakan dalam pelatihan. 
118 | Dhovi Rizal Fachrudin, et al.

\section{Acknowledge}

Terimakasih kepada Allah SWT dan semua pihak yang sudah membantu. Semoga Allah SWT membalas kebaikan semuanya. Aamiin.

\section{Daftar Pustaka}

[1] K Abdullah bin Abdul Aziz Al-jibrin, Cara Mudah Memahami Aqidah Sesuai Al-Quran Assunnah dan Pemahaman Salafush Shalih, Jakarta: Pustaka At-Tazkia, 2007.

[2] Abdullah, Dakwah Sebagai Hobi Mungkinkah?, Surabaya: Elba, 2006.

[3] Bambang S. Ma'arif, Komunikasi Dakwah: Paradigma untuk Aksi, Bandung: Simbiosa Rekatama Media, 2010.

[4] Deddy Mulyana, dkk., Metode Penelitian Komunikasi. Bandung: PT Remaja Rosdakarya, 2008.

[5] Engkus Kuswarno, Metodologi Penelitian Komunikasi Fenomenologi: Konsepsi, Pedoman, dan Contoh Penelitiannya, Bandung: Widya Padjadjaran, 2009. 